\title{
Nutritive value of ensiled pig excreta, poultry litter or urea with molasses or bakery by-products in diets for lambs
}

\author{
G.D. Trujillo ${ }^{1}$, G.J.L. Bórquez ${ }^{1}$, J.M. Pinos-Rodríguez ${ }^{2 \#}$, I.A. Domínguez-Vara ${ }^{1}$ \& R.R. Rojo ${ }^{1}$ \\ ${ }^{1}$ Facultad de Medicina Veterinaria y Zootecnia y Centro Universitario Temascaltepec, Universidad Autónoma del Estado \\ de México, Toluca, Estado de México, México \\ ${ }^{2}$ Centro de Biociencias, Universidad Autónoma de San Luis Potosí, 78377, S.L.P. México
}

(Received 2 October 2012; Accepted 3 March 2014; First published online 17 May 2014)

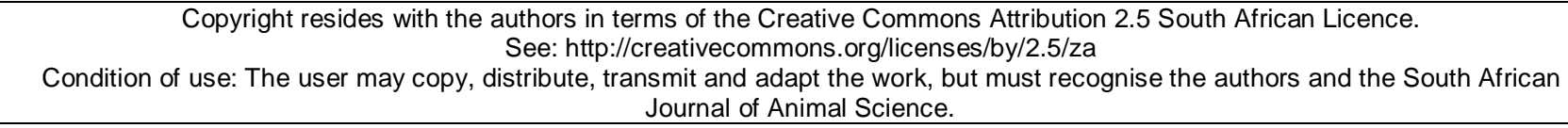
Journal of Animal Science.

\begin{abstract}
The objective of this study was to evaluate the nutritive value of maize stover silage diets containing pig excreta (PE), poultry litter $(\mathrm{PL})$ or urea as nitrogen $(\mathrm{N})$ sources, and sugarcane molasses (MOL) or bakery by-products (BBP) as energy sources. The study was designed as a $6 \times 6$ Latin square with six ruminal cannulated Hampshire rams (56 $\pm 5.7 \mathrm{~kg}$ body weight) in a $3 \times 2$ factorial arrangement of treatments. The quality of silages was good because of acceptable $\mathrm{pH}(4.1)$, texture and odour. Gas production was higher for diets with silage containing PL than that containing PE (287 vs. $269 \mathrm{~mL} / \mathrm{g} \mathrm{DM})$. The fermentation rate of diets with $\mathrm{MOL}$ was higher than with BBP $(0.07 \mathrm{vs}$. $0.05 / \mathrm{h})$. The in vitro degradation, feed intake and $\mathrm{N}$ excretion of diets that contained PL were higher than with PE silage. Feed intake for diets with silage that contained BBP and PL or PE was lower than that containing MOL. Rumen pH was increased in lambs fed diets with silage that contained urea (6.38) or PL (6.25), compared with lambs fed diets containing PE silage (6.04). Dry matter (DM) and organic matter (OM) disappearances were higher for diets with silage containing PL compared with those containing PE or urea (650 vs. 606 and $594 \mathrm{~g} / \mathrm{g} \mathrm{DM;} 620$ vs. 574 and $594 \mathrm{~g} / \mathrm{g}$ OM, respectively). The $\mathrm{N}$ retention and total tract digestion were similar for all treatments. It was concluded that diets with PL and MOL silage had higher nutritive values than those containing PE or urea.
\end{abstract}

Keywords: Digestion, fermentation rate, nitrogen balance, silage quality

\# Corresponding author: jpinos@uaslp.mx

\section{Introduction}

In the last decades, the livestock industry has experienced exponential growth that has created the need to control animal waste pollution and minimize its environmental impact (Perez Espejo, 2006). In pig production systems, faecal nitrogen $(\mathrm{N})$ excretion, which amounts to $17 \%$ of the intake, consists of the undigested protein fraction and endogenous $\mathrm{N}$ losses, mainly digestive secretions and desquamation of intestinal cells. The remaining amino acids, after protein deposition and obligatory losses, are catabolized and excreted mainly as urea (Dourmad \& Jondreville, 2007). In poultry litter (PL), crude protein (CP) content is about 20\%, mainly as uric acid (Deshck et al., 1998), though Van Ryssen (2011) recorded broiler litter containing ca. $50 \%$ true protein. Thus, pig excreta (PE) and PL are potential N sources for ruminant nutrition. Maize stover, the above-ground residue of maize plants grown for grain, is used intensively for ruminant feeding. It has a low crude protein content ( $<40 \mathrm{~g} / \mathrm{kg} \mathrm{DM}$ ), but our findings (Bórquez et al., 2009; 2010) showed that ensiling this by-product with fresh cattle manure and bakery by-products (BBP) or sugarcane molasses (MOL) produced silages with acceptable quality. Their dietary inclusion ( $250 \mathrm{~g} / \mathrm{kg}$ dry matter) in total mixed rations offers an alternative feed to finishing lambs. Using this approach, we hypothesized that ensiling maize stover with PE, PL or urea as N source with either BBP or MOL as energy source would produce silages with acceptable nutritional values, which would not depress feed intake, ruminal fermentation, digestion and $\mathrm{N}$ balance in lambs. Experimental transmission of bovine spongiform encephalopathy to sheep has been demonstrated, but the low prion level in non-nervous tissues (i.e. gut) in litter and the low probability of cross-species infection represent minimal risk of animal excreta as source of transmissible prion disease (Novakofski et al., 2005). Therefore, the objective of this study was to evaluate in 
lambs the nutritional value of total mixed rations with maize stover silage fortified with pig excreta, poultry litter or urea as $\mathrm{N}$ sources, and with molasses or bakery by-products as energy sources.

\section{Materials and Methods}

This experiment was conducted under the supervision and approval of the Academic Committee of the Faculty of Veterinary Medicine and Animal Science, Universidad Autónoma del Estado de México, according to regulations established by the Animal Protection Law, enacted by the Estado de México in México.

Fresh PE and dried PL were collected from commercial intensive farms. Pig excreta were a composite sample from a pen with finishing pigs. Dehydrated PL was a composite sample from a broiler enterprise. The chemical composition of maize stover, fresh PE, dehydrated PL, BBP and MOL was determined. The dry matter (DM) (934.01), crude protein (CP) (954.01) and ash (942.05) were analysed following the procedures of the AOAC (1997). The neutral detergent fibre (NDF) was analysed by the method of Van Soest et al. (1991) while acid detergent fibre (ADF) and acid detergent lignin (ADL) were analysed according to the methods of the AOAC (1997; 973.18) using an ANKOM $_{200}$ fibre analyser unit (ANKOM Technology Corporation, Fairport, NY, USA). The NDF was assayed without alpha amylase, but with sodium sulphite. Both NDF and ADF are expressed without residual ash. Maize stover, urea, water, PE, PL, BBP and MOL were used to prepare the silages. Water was added to the material to a level of $400 \mathrm{~g} / \mathrm{kg} \mathrm{DM}$. The control silage was prepared with urea as N source without PE and PL. Urea was dissolved in water and then mixed with BBP, MOL, and finally with maize stover. Silages were manually compacted in dark plastic bags (60 $\mathrm{x}$ $90 \mathrm{~cm}$ ) and stored indoors $\left(20^{\circ} \mathrm{C}\right)$ for a 30 -day fermentation period (Table 1$)$.

Silages were evaluated according to Frenkel (1984) as follows: i) quality appearance (acceptability: odour, 0 - 12 points; tissue structure, 0 - 5 points; colour, 0 - 3 points) making a silage with 18 to 20 points as excellent, $10-17$ points acceptable, $4-9$ points regular to bad; and $0-3$ points bad; ii) mass texture (arbitrary scale $1-5 ; 1=$ dry and $5=$ pasty). The $\mathrm{pH}$ of aqueous extracts of silages was measured using a pH meter (Benchtop Cole Parmer 05669-20, Vernon Hills, IL, USA) in $20 \mathrm{~g}$ of a silage samples (as is) blended in $200 \mathrm{~mL}$ distilled water (Shaver et al., 1984). A pH of 4.2 was considered good; 4.3 - 4.5 was regular; and $>4.5$ was bad, according to Butler \& Bailey (1973).

Table 1 Ingredients and chemical composition of silages

\begin{tabular}{|c|c|c|c|c|c|c|}
\hline & \multicolumn{2}{|c|}{ Poultry litter } & \multicolumn{2}{|c|}{ Pig excreta } & \multicolumn{2}{|c|}{ Urea } \\
\hline & MOL & BBP & MOL & BBP & MOL & BBP \\
\hline \multicolumn{7}{|l|}{ Ingredients, g/kg DM } \\
\hline Maize stover & 385 & 385 & 294 & 294 & 630 & 630 \\
\hline Poultry litter & 385 & 385 & & & & \\
\hline Pig excreta & & & 529 & 529 & & \\
\hline Urea & & & & & 30 & 30 \\
\hline Sugarcane molasses & 230 & & 177 & & & 340 \\
\hline Bakery by-product & & 230 & & 177 & 340 & \\
\hline \multicolumn{7}{|l|}{ Chemical composition, g/kg DM } \\
\hline Dry matter & 431 & 416 & 369 & 342 & 422 & 388 \\
\hline Crude protein & 165 & 170 & 119 & 131 & 160 & 151 \\
\hline Ash & 110 & 111 & 96 & 77 & 73 & 91 \\
\hline Neutral detergent fibre & 425 & 385 & 351 & 370 & 383 & 444 \\
\hline Acid detergent fibre & 290 & 214 & 201 & 198 & 237 & 250 \\
\hline Acid detergent lignin & 61 & 60 & 44 & 44 & 48 & 52 \\
\hline \multicolumn{7}{|l|}{ Silage quality } \\
\hline Acceptability (range: $10-17$ ) & 13 & 14 & 11 & 10 & 10 & 10 \\
\hline $\mathrm{pH}$ & 4.0 & 4.1 & 4.1 & 4.2 & 4.2 & 4.2 \\
\hline Texture $(1=$ dry, $5=$ pasty $)$ & 2.5 & 3.0 & 2.5 & 3.0 & 3.0 & 3.0 \\
\hline
\end{tabular}

MOL: sugarcane molasses; BBP: bakery by-product; DM: dry matter. 
For the in vivo trial, six diets with similar protein (145 g CP/kg DM) and energy (10.3 MJ ME/kg DM) contents were formulated according to the NRC (2007) for growing lambs (Table 2). The diets were randomly assigned in a Latin square design $(6 \times 6$; six treatments and six periods) to six Hampshire male rams (56 \pm $5.7 \mathrm{~kg}$ body weight) fitted with ruminal cannulae. The sheep were housed in individual metabolism cages in a naturally ventilated barn. Water and diets were offered at 08:00 and 18:00, and lambs had ad libitum access to feed (10\% refusal).

There were six $18 \mathrm{~d}$ experimental periods, each one with a $10 \mathrm{~d}$ adaptation (Brown et al., 2006) and $8 \mathrm{~d}$ sampling period. During the sampling period urine, orts and faeces were collected daily (days 10 to 18). At each daily collection, $100 \mathrm{~g} / \mathrm{kg}$ faeces were amassed and stored at $-18^{\circ} \mathrm{C}$. Urine was collected in plastic buckets containing $100 \mathrm{~mL} 5 \mathrm{~N} \mathrm{HCl}$. Urine samples $(10 \mathrm{~mL} / 100 \mathrm{~mL}$ urine) were transferred to polyethylene bottles and stored at $-18{ }^{\circ} \mathrm{C}$. At the end of the experiment, the daily samples of feed offered and feed refused per animal and period were thawed, pooled and ground for DM, ash and CP according to AOAC (1997); while NDF, ADF and ADL were determined according to Van Soest et al. (1991). Apparent total tract digestibility of DM, OM, CP, NDF and ADF, and the N-balance were calculated as described by Harris (1970).

On days $16-18$ an in sacco assay was conducted whereby bags $(5 \times 7.5 \mathrm{~cm}$; pore $50 \pm 7 \mu)$ that contained $3 \mathrm{~g} \mathrm{DM}$ each of the experimental diets (Table 2) were placed in the rumen of each lamb at 08:00 and removed (in triplicate) at 3, 8, 24, 48 and $72 \mathrm{~h}$. Before insertion into the rumen, three additional bags per sample were manually washed with water $\left(39^{\circ} \mathrm{C}\right)$ for $20 \mathrm{~min}$, and solubility was calculated. In sacco disappearances of $\mathrm{DM}, \mathrm{OM}$ and $\mathrm{CP}$ of diets were calculated using the values determined before and after ruminal incubation of bags. The analysis of ruminal DM, OM and CP kinetics was carried out using the model described by Ørskov \& McDonald (1979):

$$
P=a+b\left(1-e^{-k t}\right)
$$

where $P=$ denotes proportion ( $/ \mathrm{g} \mathrm{DM}$ ) of the material disappearance (lost through the bag) at time $t$, $a=$ ruminal soluble, readily disappearing fraction $(\mathrm{g} / \mathrm{g})$ at $0 \mathrm{~h} ; b=$ insoluble, potentially disappearing fraction (g/g DM), $k=$ disappearance constant for fraction $b$, and $\mathrm{t}=$ lag phase.

For the in vitro assay, rumen fluid was collected from two lambs fitted with ruminal cannulae and fed a total mixed ration (500 forage and $500 \mathrm{~g} / \mathrm{kg}$ concentrate). A manual system was used to measure gas production through in vitro incubation at $39^{\circ} \mathrm{C}$, according to Theodorou et al. (1994). The incubations were conducted in glass flasks $(125 \mathrm{~mL})$, sealed with a butyl rubber stopper and a screwed plastic cap, containing $90 \mathrm{~mL}$ of a culture medium (Malafaia et al., 1999), $10 \mathrm{~mL}$ of rumen inoculum and $500 \mathrm{mg}$ of DM of experimental diets (Table 2). The samples were incubated in triplicate for each treatment and time. The gas pressure was obtained by manometric readings $\left(0\right.$ to $\left.1 \mathrm{~kg} / \mathrm{cm}^{2}\right)$, while the volume was measured with a graduated syringe $(10 \mathrm{~mL})$. The determinations were done at $0,1,2,3,4,5,6,7,8,12,16,20,24,28,32$, $36,40,44,48,52,56,60,64,68$, and $72 \mathrm{~h}$ after the addition in rumen inoculum. Immediately after adding rumen inoculum, an initial reading was taken and used to standardize the pressure and to discharge the gas volume in all flasks. To quantify the gas production derived from the culture medium and the rumen inoculum, three flasks were used as blanks. The pressure and volume values were registered and added to the values of the previous readings. Thus, the cumulative pressure and volume of the fermentation gases were obtained. The volume of gas corrected by the pressure related to the incubated DM was calculated according to Theodorou et al. (1994).

The DM, OM and CP residues of each incubation time were fitted to residue of the nonlinear regression model using the NLIN procedure of SAS (2002). Data were analysed as a $6 \times 6$ Latin square design, within a $3 \times 2$ factorial arrangement of treatments (i.e. $N$ source: urea, PE, PL; energy source: BBP and $\mathrm{MOL}$ ); main effects (source of $\mathrm{N}$ ) and interaction (source of $\mathrm{N} \times$ source of carbohydrate) of silages in diets, were analysed using the mixed option of SAS. LSMEANS of SAS were used to compare means. Thus, the model included lamb (random, 5 degrees freedom (df)), period (fixed, $5 \mathrm{df}$ ), treatment (fixed, $5 \mathrm{df}$ ), interaction treatment $x$ period ( $25 \mathrm{df})$, and error $(24 \mathrm{df})$.

The cumulative gas production profiles were evaluated using the logistic model as reported by Malafaia et al. (1999): $\mathrm{V}(\mathrm{t})=\mathrm{VF} / 1+\exp [2+4 R(L-t)]$, where $V$ represents the total gas produced from the digested fraction at time $t, V F$ is equivalent to the maximum volume of gas production and its respective gas production rate $\mathrm{R}$ and the duration of the initial gas volume $\mathrm{L}$. In vitro incubation times were used to fit nonlinear regression models using the NLIN procedure (SAS, 2002). Data was analysed as a complete randomized design, within a $3 \times 2$ factorial arrangements of treatments described previously and using the GLM procedure of SAS (2002). If the interaction of $\mathrm{N}$ source with energy (E) source was significant $(P$ $<0.05)$, the LSMEANS procedure was used to compare means. Differences were accepted at $P<0.05$. 
Table 2 Ingredients and chemical composition of diets

\begin{tabular}{lrrrrrr}
\hline & \multicolumn{2}{c}{ Poultry litter } & \multicolumn{2}{c}{ Pig excreta } & \multicolumn{2}{c}{ Urea } \\
\cline { 2 - 6 } & MOL & BBP & MOL & BBP & MOL & BBP \\
\hline Ingredients, g/kg DM & & & & & & \\
$\quad$ Silage & 400 & 400 & 400 & 400 & 400 & 400 \\
Maize stover & 108 & 146 & 120 & 150 & 130 & 147 \\
Corn grain ground & 397 & 359 & 330 & 308 & 369 & 332 \\
Wheat middlings & 40 & 40 & 40 & 40 & 36 & 40 \\
Soybean meal, 44\% CP & 20 & 20 & 75 & 67 & 30 & 46 \\
Fish meal & 10 & 10 & 10 & 10 & 10 & 10 \\
Vitamin x mineral premix ${ }^{\text {a }}$ & 25 & 25 & 25 & 25 & 25 & 25 \\
Chemical composition, g/kg DM & & & & & & \\
Dry matter & 616 & 625 & 584 & 564 & 620 & 611 \\
Crude protein (CP) & 146 & 146 & 144 & 144 & 144 & 144 \\
Ash & 79 & 76 & 69 & 68 & 72 & 80 \\
Neutral detergent fibre & 306 & 373 & 317 & 355 & 416 & 418 \\
Acid detergent fibre & 152 & 190 & 160 & 185 & 233 & 216 \\
Acid detergent lignin & 43 & 44 & 30 & 40 & 45 & 46 \\
ME, MJ/kg DM ${ }^{b}$ & 10 & 10 & 10 & 10 & 10 & 10 \\
Calcium & 12 & 11 & 12 & 11 & 8 & 7 \\
Phosphorus & 6 & 6 & 6 & 7 & 3 & 4
\end{tabular}

MOL: sugarcane molasses; BBP: bakery by-product; DM: dry matter.

${ }^{a}$ Content of vitamin/mineral premix/kg: $60 \mathrm{~g}$ phosphorus; $160 \mathrm{~g}$ calcium; $100 \mathrm{~g}$ sodium; $20 \mathrm{~g}$ potassium; $4 \mathrm{~g}$ sulphur; $2 \mathrm{~g}$ magnesium; $30 \mathrm{mg}$ zinc; $0.6 \mathrm{mg}$ copper; $1.8 \mathrm{mg}$ iron; $2 \mathrm{mg}$ manganese; $20 \mathrm{mg}$ iodine; $6 \mathrm{mg}$ cobalt; $12 \mathrm{mg}$ selenium; 50000 IU vitamin A; 10000 IU vitamin D; 250 IU vitamin E.

${ }^{\mathrm{b}}$ Metabolizable energy = apparent digestibility x 0.82 (McDonald et al., 1988).

\section{Results}

Maize stover contained $929 \mathrm{~g}$ DM per $\mathrm{kg}$ and $341 \mathrm{~g} \mathrm{CP}, 76 \mathrm{~g}$ ash, $739 \mathrm{~g} \mathrm{NDF}, 521 \mathrm{~g}$ ADF and $108 \mathrm{~g}$ per $\mathrm{kg}$ of DM. Fresh PE contained $278 \mathrm{~g}$ DM per $\mathrm{kg}$ and $125 \mathrm{~g} \mathrm{CP}, 126 \mathrm{~g}$ ash, $334 \mathrm{~g}$ NDF, $126 \mathrm{~g}$ ADF and 45 $\mathrm{g} \mathrm{ADL}$ per $\mathrm{kg}$ of DM. Poultry litter contained $(\mathrm{g} / \mathrm{kg}) 880 \mathrm{DM}, 280 \mathrm{CP}, 217 \mathrm{ash}, 383 \mathrm{NDF}, 147$ ADF and 43 ADL. Urea had (g/kg) $971 \mathrm{DM}$ and $443 \mathrm{~N}$. Bakery by-product had $(\mathrm{g} / \mathrm{kg}) 890 \mathrm{DM}, 124 \mathrm{CP}, 40$ ash, $120 \mathrm{NDF}$, and 51 ADF. Sugarcane molasses had $(\mathrm{g} / \mathrm{kg})$ of MOL was $760 \mathrm{DM}, 60 \mathrm{CP}$ and 120 ash.

Some differences were found in the chemical composition of silages (Table 1). As expected, PL and urea silages had higher ash, NDF, ADF, and ADL than the other silages. Also, PL silage had higher CP and ash content than PE silage. The quality of the silages was good because of acceptable $\mathrm{pH}$, texture and odour. Chemical composition of diets differed slightly; for example, the urea diets had higher fibre content than the others, but CP and ME levels were similar for all diets (Table 2).

Gas production traits and in vitro degradation of diets were affected by N source (Table 3), while only the fermentation rate, lag phase and fractional rate of gas production at $T / 2$ were affected by energy source. Thus, potential gas production, fermentation rate and lag phase were higher for diets with PL and urea than diets containing PE silage. The fermentation rate, lag phase and fractional rate of gas production for diets with MOL were higher than diets with BBP in silage. On the other hand, the time at which half the asymptote was reached and the fractional rate of gas production at T/2 were longer for diets with BBP in the silage than with MOL. The DM, OM and NDF degradation, as well as ME of diets with PL, were similar to diets with PE in the silage. The lowest degradation values were for diets with urea compared with diets with PL and PE silage. The degradation of diets was similar for diets with MOL and BBP in silage. There were no interactions between the main factors.

Nutrient intake and rumen $\mathrm{pH}$ in lambs were affected by $\mathrm{N}$ source (Table 4). With the exception of $\mathrm{CP}$ intake, the DM, OM, NDF and ADF intakes were affected by energy (carbohydrate in silages) source. Thus, the intake of diets with PL silage was higher than with PE silage. The lowest feed intake was for lambs fed diets with urea compared with lambs fed diets with PL or PE silage. The intake of diets with BBP in silage 
was higher than for diets with MOL. However, interactions suggest that DM, NDF and ADF intake in lambs fed BBP in silage was lower than in lambs fed MOL, but it was found only in lambs fed diets with PL and PE silages, and not in lambs fed diets with urea silage. Rumen $\mathrm{pH}$ values in lambs fed diets with PL were higher than in lambs fed diets with pig excreta silage.

Table 3 Gas production and in vitro rumen degradation of diets

\begin{tabular}{|c|c|c|c|c|c|c|c|}
\hline & \multicolumn{2}{|c|}{ Poultry litter } & \multicolumn{2}{|c|}{ Pig excreta } & \multicolumn{2}{|c|}{ Urea } & \multirow{2}{*}{ SEM } \\
\hline & MOL & BBP & MOL & BBP & MOL & BBP & \\
\hline \multicolumn{8}{|l|}{ Gas production } \\
\hline $\mathrm{A}, \mathrm{mL} / \mathrm{g} \mathrm{DM}{ }^{\mathrm{N}}$ & 287 & 270 & 269 & 269 & 265 & 288 & 6.3 \\
\hline $\mathrm{B}, 1 / \mathrm{h}^{\mathrm{N}, \mathrm{E}}$ & 0.07 & 0.06 & 0.06 & 0.05 & 0.07 & 0.05 & 0.004 \\
\hline$L, h^{N, E}$ & 4.6 & 4.6 & 3.4 & 3.0 & 5.9 & 4.9 & 0.52 \\
\hline $\mathrm{T} / 2, \mathrm{~h}^{\mathrm{N}}$ & 10.0 & 11.8 & 12.9 & 11.4 & 11.9 & 14.5 & 1.45 \\
\hline$\mu$ at $\mathrm{T} / 2,1 / \mathrm{h}^{\mathrm{N}, \mathrm{E}}$ & 0.12 & 0.09 & 0.07 & 0.07 & 0.11 & 0.07 & 0.01 \\
\hline \multicolumn{8}{|l|}{ Degradation, g/kg } \\
\hline Dry matter ${ }^{\mathrm{N}}$ & 830 & 829 & 811 & 794 & 771 & 760 & 8.5 \\
\hline Organic matter ${ }^{\mathrm{N}}$ & 851 & 848 & 835 & 814 & 783 & 792 & 7.4 \\
\hline $\mathrm{NDF}^{\mathrm{N}}$ & 491 & 519 & 495 & 476 & 445 & 420 & 9.1 \\
\hline
\end{tabular}

MOL: sugarcane molasses; BBP: bakery by-product; DM: dry matter; A: potential of gas production; B: fermentation rate; $\mathrm{L}$ : lag phase prior to start of gas production; $\mathrm{T} / 2$ : time at which half the asymptote is reached; $\mu$ : fractional rate of gas production per hour at T/2; NDF: neutral detergent fibre.

${ }^{N}$ effect of $\mathrm{N}$ source $(P<0.05) ;{ }^{\mathrm{E}}$ effect of energy source $(P<0.05)$; SEM: standard error of mean.

Table 4 Intake, ruminal pH, digestion and nitrogen balance in lambs fed diets with silages

\begin{tabular}{|c|c|c|c|c|c|c|c|}
\hline & \multicolumn{2}{|c|}{ Poultry litter } & \multicolumn{2}{|c|}{ Pig excreta } & \multicolumn{2}{|c|}{ Urea } & \multirow{2}{*}{ SEM } \\
\hline & MOL & BBP & MOL & BBP & MOL & BBP & \\
\hline \multicolumn{8}{|l|}{ Intake, g/d } \\
\hline Dry matter $\mathrm{N}, \mathrm{E}, \mathrm{N} \times \mathrm{E}$ & 2043 & 1890 & 1866 & 1494 & 1727 & 1716 & 31.2 \\
\hline Organic matter $\mathrm{N}, \mathrm{E}$ & 1882 & 1746 & 1719 & 1392 & 1620 & 1579 & 28.8 \\
\hline Crude protein $^{\mathrm{N}}$ & 299 & 275 & 270 & 215 & 248 & 247 & 27.0 \\
\hline Neutral detergent fibre ${ }^{\mathrm{N}, \mathrm{E}, \mathrm{N} \times \mathrm{E}}$ & 625 & 705 & 591 & 530 & 718 & 718 & 11.4 \\
\hline Acid detergent fibre ${ }^{N, E, N \times E}$ & 311 & 359 & 298 & 276 & 402 & 371 & 15.9 \\
\hline \multicolumn{8}{|l|}{ Digestion, g/kg } \\
\hline Dry matter & 681 & 668 & 682 & 660 & 700 & 654 & 11.2 \\
\hline Organic matter & 698 & 677 & 684 & 676 & 712 & 678 & 19.0 \\
\hline Crude protein & 750 & 734 & 734 & 750 & 813 & 767 & 19.1 \\
\hline Neutral detergent fibre & 454 & 541 & 469 & 484 & 607 & 520 & 21.1 \\
\hline Acid detergent fibre & 429 & 517 & 454 & 477 & 587 & 497 & 22.8 \\
\hline \multicolumn{8}{|l|}{$\mathrm{N}$ balance, $\mathrm{g} / \mathrm{d}$} \\
\hline Intake ${ }^{N}$ & 48.4 & 44.5 & 43.8 & 35.0 & 40.0 & 40.2 & 2.24 \\
\hline Faeces $^{N}$ & 11.3 & 12.5 & 12.2 & 8.9 & 10.9 & 9.3 & 1.39 \\
\hline Urine $^{N}$ & 32.2 & 26.6 & 26.0 & 21.2 & 23.1 & 24.8 & 2.16 \\
\hline Retention & 4.9 & 5.4 & 5.6 & 4.9 & 6.0 & 6.1 & 0.89 \\
\hline Rumen $\mathrm{pH}^{\mathrm{N}}$ & 6.24 & 6.26 & 6.01 & 6.07 & 6.41 & 6.35 & 0.11 \\
\hline
\end{tabular}

MOL: sugarcane molasses; BBP: bakery by-product; ${ }^{\mathrm{N}}$ effect of $\mathrm{N}$ source $(P<0.05) ;{ }^{\mathrm{E}}$ effect of energy source $(P<0.05)$; $\mathrm{N \times E}$ interaction of $\mathrm{N}$ source $x \mathrm{E}$ source $(P<0.05)$; SEM: standard error of mean. 
The highest $\mathrm{pH}$ values were found in lambs fed diets with urea silage. There were no interactions in rumen $\mathrm{pH}$ values.

The total tract digestion of diets was similar. The $\mathrm{N}$ balance trial indicated that $\mathrm{N}$ intake and $\mathrm{N}$ content in faeces and urine were affected only by $\mathrm{N}$ source. Lambs fed diets with poultry litter silage had higher $\mathrm{N}$ intakes and $\mathrm{N}$ excretion than lambs fed pig excreta silage. The lowest $\mathrm{N}$ intake and excretion values were found in lambs fed diets with pig excreta silages compared with lambs fed diets with poultry litter or urea silage when BBP was used as the carbohydrate source. However, the $\mathrm{N}$ retention in lambs fed experimental diets with the various types of silages was similar.

The potential disappearance and degradation rate of DM and OM were not affected by $\mathrm{N}$ or energy sources in silages, but solubility and potential disappearance of those fractions were affected by $\mathrm{N}$ source (Table 5). Also, total degradation CP of the diets was affected by N source in the silages. Thus, diets with pig excreta or urea silage had higher soluble fractions of DM and OM than diets with poultry litter silage. Total degradation of $\mathrm{CP}$ of diets with pig excreta or urea silage was higher than diets with poultry litter silage. Potential degradation of DM and OM was lower in diets with pig excreta and MOL silage, but was higher for CP.

Table 5 In sacco disappearance kinetics of diets $(\mathrm{g} / \mathrm{g})$

\begin{tabular}{|c|c|c|c|c|c|c|c|}
\hline & \multicolumn{2}{|c|}{ Poultry litter } & \multicolumn{2}{|c|}{ Pig excreta } & \multicolumn{2}{|c|}{ Urea } & \multirow{2}{*}{ SEM } \\
\hline & MOL & BBP & MOL & BBP & MOL & BBP & \\
\hline \multicolumn{8}{|l|}{ Dry matter $^{a}$} \\
\hline Soluble fraction ${ }^{N}$ & 0.180 & 0.204 & 0.233 & 0.181 & 0.193 & 0.222 & 0.018 \\
\hline Potential degradation ${ }^{\mathrm{N}}$ & 0.650 & 0.629 & 0.606 & 0.640 & 0.618 & 0.607 & 0.018 \\
\hline Total degradation & 0.830 & 0.833 & 0.839 & 0.821 & 0.811 & 0.829 & 0.020 \\
\hline Degradation rate (\%/h) & 0.011 & 0.010 & 0.011 & 0.011 & 0.010 & 0.009 & 0.002 \\
\hline \multicolumn{8}{|l|}{ Organic matter $^{\mathrm{a}}$} \\
\hline Soluble fraction ${ }^{\mathrm{N}}$ & 0.176 & 0.198 & 0.229 & 0.180 & 0.185 & 0.203 & 0.018 \\
\hline Potential degradation ${ }^{\mathrm{N}}$ & 0.628 & 0.618 & 0.574 & 0.632 & 0.594 & 0.593 & 0.017 \\
\hline Total degradation & 0.804 & 0.816 & 0.803 & 0.812 & 0.779 & 0.816 & 0.018 \\
\hline Degradation rate $(\% / \mathrm{h})$ & 0.014 & 0.012 & 0.015 & 0.012 & 0.012 & 0.011 & 0.002 \\
\hline \multicolumn{8}{|l|}{ Crude protein ${ }^{a}$} \\
\hline Soluble fraction & 0.128 & 0.179 & 0.164 & 0.176 & 0.168 & 0.197 & 0.020 \\
\hline Potential degradation ${ }^{\mathrm{N}}$ & 0.245 & 0.222 & 0.352 & 0.233 & 0.258 & 0.211 & 0.040 \\
\hline Total degradation ${ }^{\mathrm{N}}$ & 0.373 & 0.401 & 0.516 & 0.409 & 0.426 & 0.408 & 0.034 \\
\hline Degradation rate $(\% / h)$ & 0.013 & 0.014 & 0.014 & 0.013 & 0.013 & 0.009 & 0.004 \\
\hline
\end{tabular}

MOL: sugarcane molasses; BBP: bakery by-product; ${ }^{a}$ Lag phase (h) for dry matter and organic matter was not detected; lag phase of crude protein was for poultry litter + MOL, 1.8; poultry litter + BBP, 1.4; pig excreta + MOL, 1.8; pig excreta + BBP, 2.2; urea + MOL, 1.4; urea + BBP, 1.6; ${ }^{\mathrm{N}}$ Effect of $\mathrm{N}$ source $(\mathrm{P}<0.05)$; SEM: standard error of mean.

\section{Discussions}

The silage quality was acceptable and values are in agreement with our previous findings (Bórquez et al., 2010). Most of the results indicated that ensiling PL with MOL and adding it to diets offered a higher feeding value than ensiling PE or urea with MOL or BBP. This can be explained by differences in digestibility and then in feed intake. The addition of MOL to PL may enhance silage quality.

Parthasarathy \& Pradhan (1982) studied the nutritive value of PL silage with wheat straw, bagasse or sawdust, and found that there was no effect on degradability of DM and CP when they fed livestock this silage. Al-Rokayana et al. (1998) studied silage made with sorghum straw, PL and MOL, including different levels in diets, in lambs, and found that digestibility of DM, OM and CP was higher than the control (without silage). This suggests that the soluble carbohydrates in MOL that were available to the bacteria were an adequate source of energy (Bórquez et al., 2009). Because both in vitro and in sacco assays indicated that diets with poultry litter silages had higher degradation than others, the higher feed intake in lambs fed diets with PL plus MOL silages could explain the absence of differences in total tract digestion of diets. 
Ahmed \& Talib (2008) evaluated the nutritive value of deep-stacked broiler litter in ruminant nutrition and found that the DM intake and palatability of the diet were not affected in goats and sheep. Mthiyane et al. (2001) reported that the degradability of DM was greater with PL and sugarcane stem silage at $48 \mathrm{~h}$ fermentation than the control without silage. In effect, with cattle manure silages, Sarwar et al. (2006) and Borquez et al. (2009) found significant increases of feed intake of the diets, without any effect on total tract digestion. According to these researchers, the increment in feed intake might be because of an improvement in DM and OM digestibility, as was found in our in vitro and in sacco assays. A likely reason for the MOL effect on cell wall digestibility is the difference in DMI (Weiss \& Wyatt, 2004). This suggests that nonstructural carbohydrates of MOL had important effects on ruminal fermentation, such as those found with non-structural carbohydrate supplementation (AlZahal et al., 2007). Although PL silage showed the highest nutritional value, there is a dearth of information on pig excreta silage, though acceptable values were reported when it was added to diets for ruminants (Bhattacharya \& Taylor, 1975).

When BBP was used in PE silage, the lag time $(L, h)$ was lower, which could be because of the type of fibre of pig waste and better nutrient conditions for microorganisms provided by BBP. The digestion of the experimental diets containing PE was similar to that reported by Bhattacharya \& Taylor (1975), who suggested that ensiling PE may increase animal acceptability and help in pathogen control (Arndt et al., 1979). Chaudhry et al. (1996) made silage with PL and MOL and included this silage in diets for lambs. They found that digestibility of DM and CP increased. Unfortunately, we did not study silage pathogens, but the methodology that was used to ensile pig excreta was similar to that of Borquez et al. (2009; 2010), in which $\mathrm{pH}$ of cattle manure silages was lower than 4.2. This suggests that undesirable faecal microorganisms (coliforms, salmonella, shigella, proteus), yeasts and moulds would be eliminated, a finding that has been reported for animal excreta silages (Cornman et al., 1981). Iñiguez-Cobarrubias et al. (1990) studied silage of PE with wheat straw, included at different levels. They found that CPD (crude protein digestibility) was higher in diets with 44\% PE silage as opposed to $22 \%$; and after seven days of fermentation, coliforms were eliminated. Because in our investigation there was no effect in $\mathrm{N}$ retention between treatments, this could mean that the silages studied were equally effective as N sources for growing lambs. Rude \& Rankins (1993) made silage with $\mathrm{PL}$ and corn forage, Johnson grass, sorghum and Bermuda grass, and found higher $\mathrm{N}$ retention and digestibility of DM, OM, and NDF when mixing corn forage and PL. Jakhmola et al. (1984) studied cattle waste mixed with green maize and wheat bhoosa enriched with urea and MOL prior to ensiling (wastelage). They found that urea adversely affected wastage characteristics, while MOL had a beneficial effect on the fermentation process. Moreover, digestibility of DM, OM, cell content, hemicelluloses and soluble ash decreased with increasing levels of wastelage in the diet, but the $\mathrm{N}$ retention balance was reduced.

Several safety concerns are associated with the use of animal manure as a feed ingredient. There is the potential risk of residues of microbial pathogens, drugs and other chemicals, which may harm livestock or transfer volatile residues in animal products to humans. Each country must therefore enact a law regulating the use of manure as a feed ingredient for animals, especially for young and lactating ruminants.

\section{Conclusion}

Diets with silages made from maize stover, poultry litter (as $\mathrm{N}$ source) and sugarcane molasses (as energy source) had higher feeding values than diets containing silages fortified with pig excreta or urea (as $\mathrm{N}$ source) and bakery by-products (as energy source) for lambs. Ensiling poultry litter or pig excreta with sugarcane molasses or bakery by-products and adding them to diets could reduce feed costs and environmental effects. Results indicated that adding these animal excreta to blended rations has been satisfactory for lambs, without apparent harmful effects, but further studies should be performed with a larger number of experimental units in order to support information for sheep producers.

\section{Acknowledgement}

We acknowledge the Universidad Autónoma del Estado de México and the National Council of Science and Technology (CONACYT) for the economic support to the project 2238/2006 and the opportunity to carry out master's science studies.

\section{References}

Ahmed, F.A. \& Talib, N.H., 2008. Digestibility, degradability and dry matter intake of deep-stacked poultry litter by sheep and goats. J. Anim. Vet. Adv. 7, 1474-1479.

Al-Rokayan, S.A., Naseer, Z. \& Chaudhry, S.M., 1998. Nutritional quality and digestibility of sorghum-broiler litter silages. Anim. Feed Sci. Technol. 75, 65-73.

AlZahal, E., Kebreab, E., France, J. \& McBride, B.W., 2007. A mathematical approach to predicting biological values from ruminal pH measurements. J. Dairy Sci. 90, 3777-3785. 
AOAC, 1997. Official Methods of Analysis (16th ed). Association of Official Analytical Chemists. Arlington, Virginia, USA.

Arndt, D.L., Day, D.L. \& Hatfield, E.E., 1979. Processing and Handling of Animal Excreta for Refeeding. J. Anim. Sci. 48, 157-162.

Bhattacharya, A.N. \& Taylor, J.C., 1975. Recycling animal waste as a feedstuff. A review. J. Anim. Sci. 41, 1438-1457.

Bórquez, J.L., González-Muñoz, S.S., Pinos-Rodríguez, J.M., Domínguez, I., Bárcena, J.R., Mendoza, G.D., Cobos, M.A. \& Bueno, G., 2009. Feeding value of ensiling fresh cattle manure with molasses or bakery byproducts in lambs. Livest. Sci. 122, 276-280.

Bórquez, J.L., Pinos-Rodríguez, J.M., González-Muñoz, S.S., Domínguez, I., Bárcena, J.R., Mendoza, G.D. \& Cobos, M.A., 2010. Use of different kind of silage dairy cattle manure in lamb nutrition. Ital. J. Anim. Sci. 9, 129-133.

Brown, M.S., Poce, C.H. \& Pulikanti, R., 2006. Adaptation and beef cattle to high-concentrate diets: performance and ruminal metabolism. J. Anim. Sci. 84, E25-E33.

Butler, G.W. \& Bailey, R.W., 1973. Chemistry and Biochemistry of Herbage. Academic Press, New York, NY, USA.

Chaudhry, S.M., Fontenot, J.P., Naseer, Z. \& Ali, C.S., 1996. Nutritive value of deep stacked and ensiled broiler litter for sheep. Anim. Feed Sci. Technol. 57, 165-173.

Cornman, A.W., Lamm, W.D., Webb Jr., K.E. \& Fontenot, J.P., 1981. Ensiling cattle waste with rye straw as a diet supplement for ruminants. J. Anim. Sci. 52, 1233-1239.

Deshck, A., Abo-Shehada, M., Allonby, E., Givens, D.I. \& Hill, R., 1998. Assessment of the nutritive value for ruminants of poultry litter. Anim. Feed Sci. Technol. 73, 29-35.

Dourmad, J.Y. \& Jondreville, C., 2007. Impact of nutrition on nitrogen, phosphorus, $\mathrm{Cu}$ and $\mathrm{Zn}$ in pig manure, and on emissions of ammonia and odors. Livest. Sci. 112, 192-198.

Frenkel, M.A., 1984. Forage Conservation: Hays, Silages, Dehydration. Albatros, Buenos Aires, Argentina.

Harris, L.E., 1970. Nutrition research techniques for domestic and wild animals. An International Record System and Procedures for Analyzing Samples. Lorin E. Harris, 1408 Highland Drive, Logan Utah, USA, Vol. 1.

Iñiguez-Covarrubias, G., Cuaron-Ibarguengoitia, J.A., Perez-Gavilan, P., de la Torre-Martinez, M. \& MaganaPlaza, I., 1990. Fermentation characteristics, digestibility and performance of ensiled swine waste, wheat straw and cane molasses fed to sheep. Biological Wastes 34, 281-299.

Jakhmola, R.C., Kamra, D.N., Singh, R. \& Pathak, N.N., 1984. Fermentation of cattle waste for animal feeding. Agricultural Wastes 10, 229-237.

Malafaia, P.A.M., Filho, S.C.V. \& Vieira, R.A.M., 1999. Kinetic parameters of ruminal degradation estimated with a non-automated system to measure gas production. Livest. Prod. Sci. 58, 65-73.

McDonald, P., Edwards, R.A. \& Greenhalgh, J.F.D., 1988. Nutrición Animal. 4a. Edición. Edit. Acribia, S.A. Zaragoza, España. p. 238.

Mthiyane, D.M.N., Nsahlai, I.V. \& Bonsi, M.L.K., 2001. The nutritional composition, fermentation characteristics, in sacco degradation and fungal pathogen dynamics of sugarcane tops ensiled with broiler litter with or without water, Anim. Feed Sci. Technol. 94, 171-185.

Novakofski, J., Brewer, M.S., Mateus-Pinilla, N., Killefer, J. \& McCusker, R.H., 2005. Prion biology relevant to bovine spongiform encephalopathy. J. Anim. Sci. 83, 1455-1476.

NRC, 2007. Nutrient Requirements of Small Ruminants. National Research Council, The National Academic Press, Washington, D.C., USA.

Ørskov, E.R. \& McDonald, I., 1979. The estimation of protein degradability in the rumen from incubation measurements weighted according to rate of passage. J. Agric. Sci. 92, 499-503.

Parthasarathy, M. \& Pradhan, K., 1982. Fermentation characteristics and feeding value of ensiled poultry litter containing wheat straw, bagasse or sawdust. Anim. Feed Sci. Technol. 7, 341-349.

Perez Espejo, R., 2006. Costs of the wastewater standard in pig production in Mexico. Environ. Develop. Sustain. 8, 391-411.

Rude, B.J. \& Rankins Jr., D.L., 1993. Evaluation of bermudagrass (Cynodon dactylon) and johnsongrass (Sorghum halepense) as alternatives to corn forage (Zea mays) for ensiling with poultry litter. Anim. Feed Sci. Technol. 44, 101-111.

Sarwar, M., Nisa, M., Hassan, Z. \& Shahzad, M.A., 2006. Influence of urea molasses treated wheat straw fermented with cattle manure on chemical composition and feeding value for growing buffalo calves. Livest. Sci. 105, 151-161.

SAS, 2002. SAS User's Guide: Statistics. SAS Institute. Cary, N.C., USA.

Shaver, R.D., Erdman, R.A. \& Vadersall, J.H., 1984. Effects of silage pH on voluntary intake of corn silage. J. Dairy Sci. 67, 2045-2049. 
Theodorou, M.K., Williams, B.A., Dhanoa, M.S., McAllan, A.B. \& France, J., 1994. A simple gas production method using a pressure transducer to determine the fermentation kinetics of ruminant feeds. Anim. Feed Sci. Technol. 48,185-197.

Van Soest, P.J., Robertson, J.B. \& Lewis, B.A., 1991. Methods for dietary fiber, neutral detergent fiber, and nonstarch polysaccharides in relation to animal nutrition. J. Dairy Sci. 74, 3583-3597.

Van Ryssen, J.B.J., 2001. Poultry litter as a feedstuff for ruminants: A South African Scene, S. Afr. J. Anim. Sci. http:/www.sasas.co.za/Popular/Popular.html.

Weiss, W.P. \& Wyatt, D.J., 2004. Digestible energy values of diets with different fat supplements when fed to lactating dairy cows. J. Dairy Sci. 87, 1446-1454. 